\title{
A Study on the Non-performing Loans Market in China
}

\author{
Yue Zhong, \\ ${ }^{1}$ HKU Business School, The University of Hong Kong, Hong Kong SAR, China \\ *Corresponding author. Email: winniez1201@gmail.com
}

\begin{abstract}
In 2008, the subprime mortgage market in the US collapsed as a result of falling housing prices, and kicked start a global financial crisis. Growing at a fast rate, the subprime mortgage market had accumulated a high level of risks before its collapse. In the post-global crisis period, the non-performing loans (NPLs) market in China experienced similar growth, leading to concerns of potential failure. This paper, with reference to the US subprime market in the 2000s, develops an explanation of the risks related to the Chinese NPLs market, by identifying the trend and the causes of the growth. This paper then evaluates the corresponding prevention measures in terms of corporate governance and government regulations. The findings of this research suggest that the risks in the Chinese NPLs market will remain at a controllable level, while further measures are required to make the market vibrant.
\end{abstract}

Keywords: Chinese loans market, US subprime mortgage market, Financial crisis.

\section{INTRODUCTION}

In 2007, the huge subprime mortgage market in the US collapsed, following the crash of domestic housing prices. Financial institutions in the US, which had been relying on mortgage-backed securities (MBSs) to thrive for years, struggled to deal with these "toxic assets" on their balance sheet. The bankruptcy of Lehman Brothers on $15^{\text {th }}$ September, 2008, marked the beginning of a global financial crisis, in which the world's financial system almost broke down, and the total loss in the global economy amounted to $\$ 2$ trillion - a negative $4 \%$ in global economic growth [14].

10 years after the subprime crisis, the nonperforming loans (NPLs) market in China has seen continuous and fast growth, with all NPLs and other stressed assets valued at \$1.5 trillion [16]. Concerns have been raised regarding this market. This paper, with reference to the subprime mortgage market in the US, aims to examine whether a collapse will happen in the future Chinese NPLs market. The paper will first introduce the current situation of the Chinese NPLs market and identify the existing risks. Drawing lessons from the corporate governance failure in the US, the paper will then analyze the corporate governance practices of Chinese financial institutions, and evaluate the problems and improvements. Finally, the paper will study the current government interventions to investigate the level of risks in near future.

\section{RISKS IN THE NON- PERFORMING LOANS MARKET}

\subsection{The US Subprime Mortgage Market and Subprime Crisis in the 2000s}

The US housing market experienced a boom since 2003, following an announcement of a lowering federal fund rate. Subprime mortgages, which target people who wanted to own a house but had bad credit history, were introduced to these house buyers, charging a higher interest rate. Peaked in the mid-2000s, the US market of subprime mortgages once amounted to $\$ 1.2$ trillion, which is a $600 \%$ increase from 2001 [7].

While the subprime mortgage itself only took a small portion of the subprime mortgage market, MBSs were dominant in the market. "Figure 1" presents the volume of MBSs in the US in the past 20 years. 


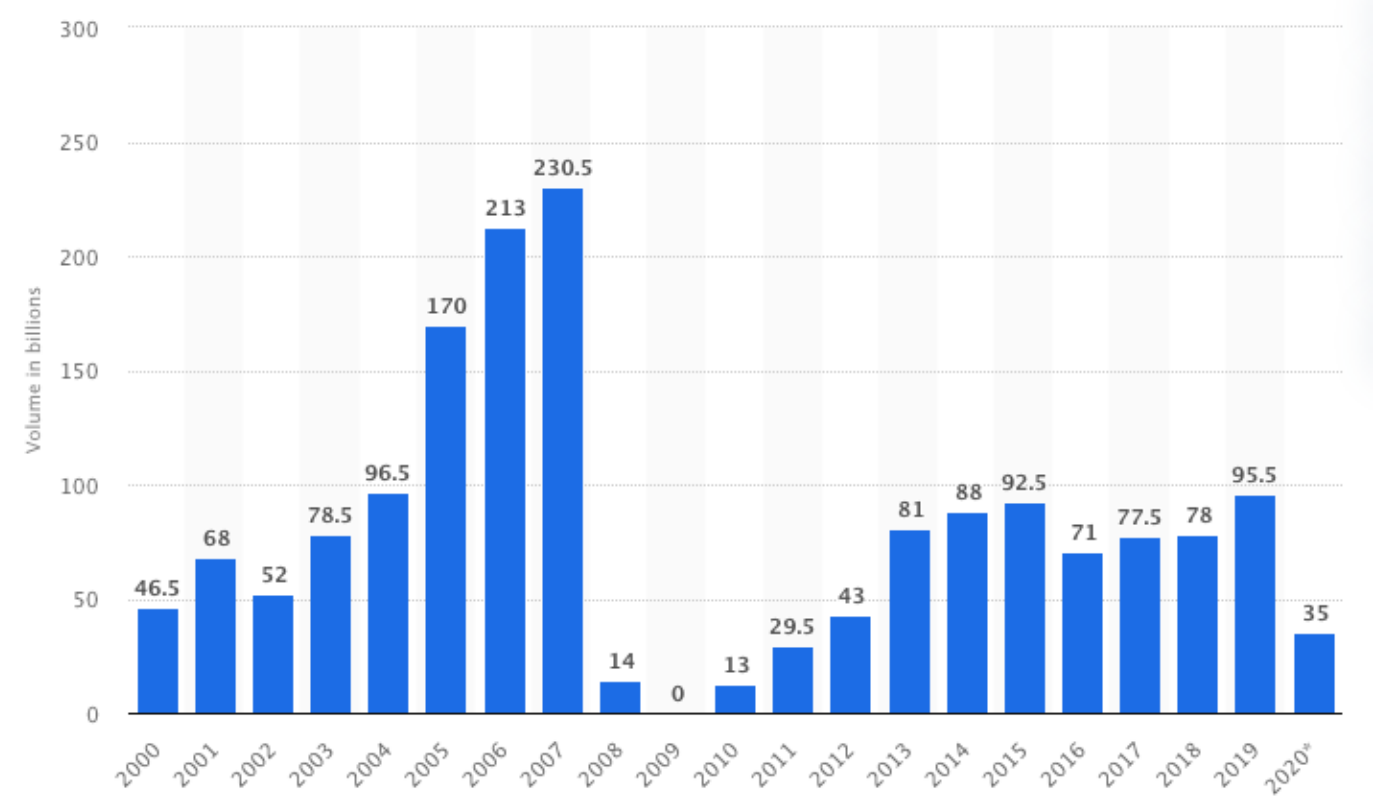

Figure 1 Volume of commercial mortgage-backed securities (CMBS) originations in the United States from 2000 to 2020 (in billions). [18].

Since 2003, the volume of MBSs in the US surged, reaching a record high of $\$ 230.5$ billion in 2007 , before it encountered a crash in 2008 [18]. Given a higher yield of return, the investors of MBSs failed to identify potential risks - the standard of the mortgages had dropped during the boom of the housing market. Given a drop in asset prices, the rate of default increased significantly, leading to a great portion of "toxic assets" and an ultimate failure of the MBSs market [7].

\subsection{Problems in the Growing Chinese Non-performing Loans Market}

Similar to the US subprime mortgage market in the 2000s, in recent years, the Chinese NPLs market observed a large growth. Three classes of loans are defined as NPLs: sub-standard (25\%), doubtful (50\%), and loss (100\%). "Figure 2" demonstrates the value of NPLs in Chinese listed banks, and "Figure 3" represents the level of NPLs ratio in China in the post-financial crisis period. 


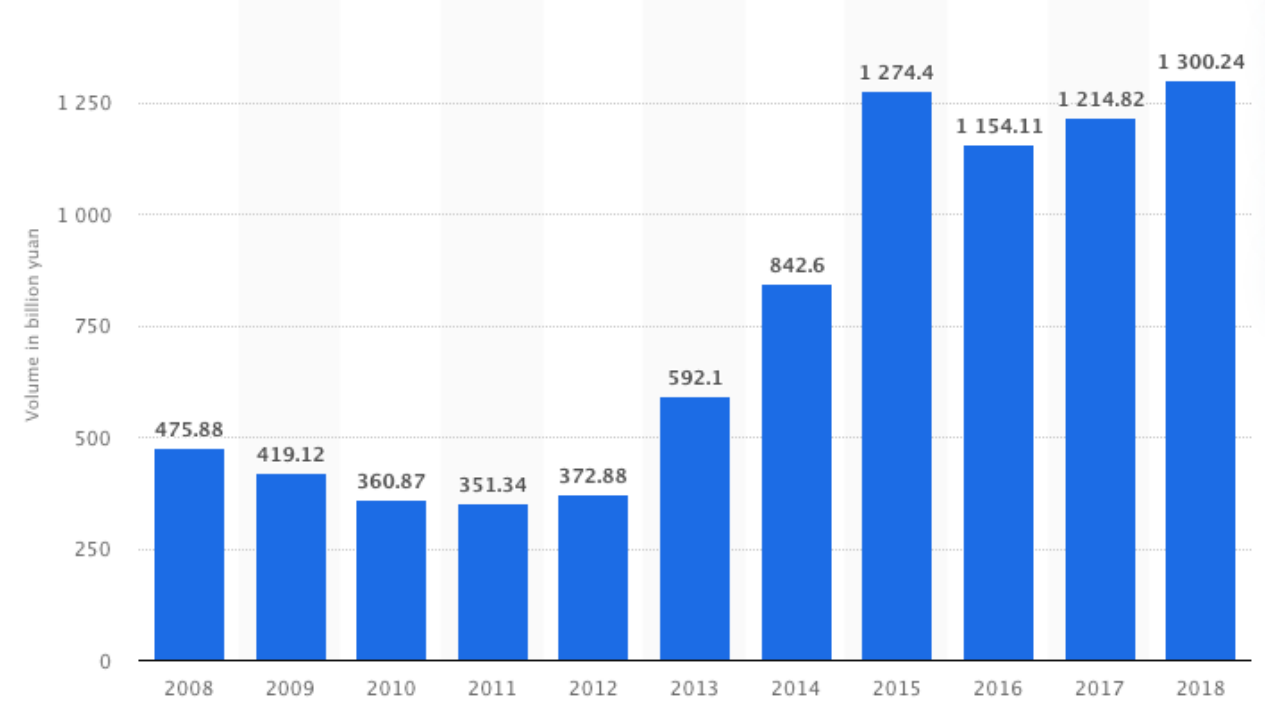

Figure 2 Value of non-performing loans (NPL) of listed Chinese banks between 2008 and 2018 (in billion yuan) [19].

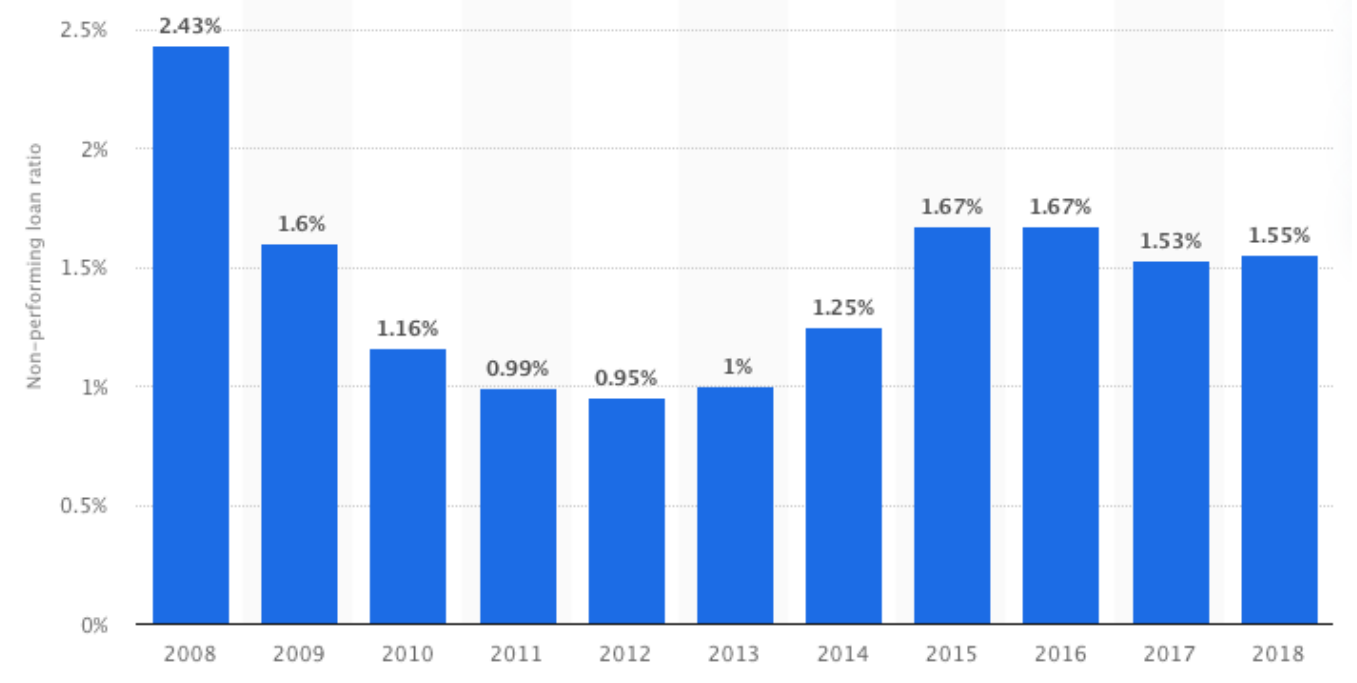

Figure 3 Non-performing loan (NPL) ratio of China's listed banks between 2008 and 2018 [17].

As shown by the figures, the total value of NPLs in Chinese listed bank increased by more than 800 billion yuan within 10 years after the 2008 Financial Crisis [19]. The NPLs ratio in China's listed banks had fluctuated, but became relatively stable at around $1.5 \%-2.0 \%$ after 2015 , shown in "Figure 3". Announced by the China Banking and Insurance Regulation Commission, the latest NPLs ratio of 2020 is at $1.92 \%$ [21], higher than the level before 2019. It is worth noting that such ratios are lower than that of the more developed countries in the west, and international analysts have questioned the accuracy of data. According to a study at PwC, it will be more accurate to estimate the NPL ratios in China at a level between 3\% and 5\% [15].

Several factors contributed to the recent rise of NPLs in China. $\mathrm{Li}$ and $\mathrm{Ng}$, who studied the normalization effects NPLs in the context of the late 1990s, have found that poor payment practices became more common in late the 1990s, though 
some firms resisted carrying NPLs [12]. In recent 10 years, as a result of "an unprecedented 5-year debt binge and a slowing economy" [16] and the stimulus package, NPLs became even more prevalent. Such an increase in NPLs was found to be more concentrated in heavy industries, which require heavy capital, but face a falling demand and become incapable to pay back the loans. In near future, the rise of NPLs is likely to continue, making the financial system more vulnerable to a fall in asset price - it is estimated that a $30 \%$ drop in property prices is an unaffordable loss to the banks [16].

NPLs securities in China also observed a growth in value and number of deals. Securitization is seen as a commercial solution for the increasing NPLs level, as it tries to spread the nondiversifiable risks through the whole financial system to make it seem easier to deal with. Opportunities are found in the Chinese market of NPLs securities. An estimated $\$ 1.1$ billion of international capital flowed into the market [16], indicating a growing and opening market of NPLs portfolios.

However, concerns have been raised. While the NPLs ratio is considered to be "healthy" as compared to European countries, international analysts criticized the rise of problematic lending practices, which can undermine the quality of banks' assets. Ba, an economist of CBRC, pointed out that the market is still far from maturity with several major problems [4]. Firstly, variation in the underlying assets leads to difficulties in price setting. NPLs are highly related to the economic environment, policies and production cycle. Risks can accumulate during an economic downturn, such as the coronavirus crisis. In provinces where heavy industries are concentrated, it can be more difficult to recover the NPLs. While risk diversification is necessary, a diversified portfolio can result in difficulties in assessing the qualities of the underlying assets. Secondly, asymmetric information is common among different parties in China, including investors and intermediary institutions, as there is a lack of transparency regarding information such as a line of credit of the borrowers and the expected payment received. Institutions and investors face challenges in receiving information on the asset pool timely, affecting the valuation of the portfolio. Lastly, the single structure of the deal is unlikely to meet the requirements from both investors and regulatory bodies. Only one special purpose vehicle (SPV), a subsidiary to isolate financial risks, exists in the current structure of deal, increasing risks related to sales, bankruptcy isolation and taxes [4]. Overall, the market is still at an early stage with uncertainties. In the next sections, the paper will evaluate how some risk-preventing measures can keep a vibrant market with a controllable level of risks.

\section{MEASURES TO PREVENT FAILURES OF NPLS MARKET}

To effectively reduce the risks of failures in the Chinese NPLs market, corporate governance of financial institutions and government interventions are critical. This section will first assess the current measures in these two areas, and gain some insights for future practices in China.

\subsection{Correct Corporate Governance}

\subsubsection{Corporate Governance Failure and Financial Crisis}

Resolving the agency problems requires correct corporate governance practices. Failures of corporate governance can directly lead to the failure of the company. Given the network effects and the large scale of the company, such a failure is sometimes unaffordable for the industry and even the economy.

The bankruptcy of Lehman Brothers is an example of corporate governance failure which brought disastrous impacts to the global financial sector. To hide its high level of leverage, Lehman Brothers relied on "Repo 105", a sale and repurchase agreement, which converts "financing" to "sales" activities in the balance sheet [20]. The excessively high compensation also incentivized the executives to make risky decisions, as they could be benefited from the short-term growth of the company, and thus pay little attention to future risks [1]. Indeed, the failure of corporate governance was common among US financial institutions in the 2000s. Some major banks should have identified the risks, but they were not capable to balance growth in financial figures and liquidity needs [11]. Learning from the subprime crisis, weaknesses of corporate governance should be seen as a sign of potential future crisis. 


\subsubsection{Corporate Governance of Financial Institutions in China}

The recent scandals of Huarong Asset Management Co., one of the largest AMCs in china, have revealed problems of corporate governance in the Chinese financial industry. The former chair of Huarong, was found guilty of corruption, receiving bribes amounted to $\$ 277$ million [2]. The total outstanding debt of Huarong in China and overseas has exceeded $\$ 42$ billion. After the failure was uncovered, the price of Huarong's bond, fell unprecedentedly to $\$ 0.52$, the lowest in record [2]. The failure of Huarong could have significant spillover effects on the Chinese financial market. The confidence of investors can be affected, as the risks of debt securities in the market will be reassessed. Prices of stocks and bonds are likely to fall in the process of reassessment and restructuring.

In state-owned enterprises (SOEs) of China, agency problems are commonly found as a result of the conflict of interest between the controlling shareholders and minority shareholders. Jiang and Kim pointed out that, the controlling shareholders such as the chair, can make decisions that result in "insider-outsider conflicts" [8]. Such conflicts of interests are worsened by the pyramid structure ownership structure commonly found in Chinese firms. Political connections owned by the firms' executives also undermine minority shareholders' interests, as the companies gain advantages in covering negative information in terms of performance and finance. Meanwhile, the minority shareholders are not able to replace these insiders even when there is a poor performance, making this agency problem a challenge to the SOEs, including the state-owned asset management companies (AMCs) and banks [8].

Nonetheless, some improvements have been made in the corporate governance of the large commercial banks, claimed by Deloitte after carrying an investigation in the big six banks [6]. Since 2004, the corporate governance structure was established in the six banks according to international standards, with the board of directors being the center. The banks also improve practices such as board composition diversification, standard decision-making process and information disclosure. Keeping the essence of the international models, some Chinese characteristics were inserted into corporate governance [6]. For example, the Party Organization not only plays an internal role in governance, but also meets the external requirements of the ruling party. Mechanisms of multi-channel communication are also built to keep the shareholders informed [6].

These large commercial have learned from the international experiences, by establishing an "internal control system". The system will help to guarantee the standard of financial reporting and evaluate risks accurately and quantitatively, and thus provide support to the board in strategy advisory. To reduce agency problems and seek a good balance between risks and performance, the banks put in efforts to raise awareness of risk control among all employees [6].

\subsection{Reasonable Government Administrative Intervention}

The Chinese government is expected to play a more powerful role in regulating the finance sector, especially the growing NPLs market. Regulations and supervision have been strengthened to fight against violating behaviors in the financial sector. Last year, the regulatory body issued violations against over 3,000 financial institutions and 4,000 individuals [3]. Greater regulatory power is also applied to the small and medium-sized banks and insurance institutions, which mainly provide services for small and medium enterprises (SMEs) and customers in rural areas. These institutions, in which problematic lending practices are common, are also less capable of risk management [9]. According to China Banking and Insurance Regulatory Commission (CBIRC), up to $95 \%$ of the net capital of a rural bank was lent, and identified to be non-performing. CBIRC has been targeting these institutions to improve their corporate governance practices and mitigate risks. Such interventions include raising capital for the banks with high debt levels through sales to the state-owned banks. CBIRC has been pressurizing the banks to disposing NPLs. In 2020, a total amount of 3.02 trillion yuan of non-performing assets were disposed [5]. Such efforts are expected to continue in future to control the NPLs ratio at around $2 \%$, and avoid a sharp increase.

The rise of online finance also attracted the attention of the Chinese regulatory bodies. In the past few years, online finance, including Ant and WeBank, has changed the behaviors of Chinese in the finance sectors. These online platforms have attracted a great number of users in microloans, insurance and investments with their high profitability and convenience. Leveraging the "Credittech" business, the revenue of Ant increased by $59.5 \%$ in the first two quarters of 2020 [13]. 
However, such a success is also contributed by the lack of restrictions on the debt ratios and NPLs ratio. The lending practices of these platforms are accumulating greater risks with their high level of leverage. Ant's IPO to Shanghai and Hong Kong was therefore paused in order to reduce uncertainties and monopolistic behaviors. Although some analysts see this halt to be connected with political concerns on Jack Ma, it still indicates a strengthened regulation to some extent. It is expected that greater regulations targeting fintech firms and online finance platforms will be enforced.

\section{CONCLUSION}

This paper examines the problems in the bad loan market and corporate governance practices of financial institutions in China. It is confirmed that the market of NPLs in China will continue to grow, and big failures of corporate governance still happen. Therefore, whether risks will accumulate to an uncontrollable level will largely depend on improvements in corporate governance and government interventions.

This research also provides measures to reduce the risk of the collapse of the bad credit market. The Chinese government is expected to continue taking control of the financial industry and the NPLs market. Regulations on the traditional finance sector will be strengthened, with an aim to control both the NPLs ratio and value. The government will also overcome the previous regulatory gaps and mitigate risks involved in the high level of leverage found in the online finance sector. With such a powerful government intervention, the risks of NPLs market failure in the near future are under control, while more innovations are necessary to make the market more vibrant.

\section{AUTHORS' CONTRIBUTIONS} Zhong.

This paper is independently completed by Yue

\section{REFERENCES}

[1] Bebchuck, L. A., Cohen, A., \& Spamann, H. The Wages of Failure: Executive Compensation at Bear Stearns and Lehman 2000-2008. Yale Journal on Regulation 27(2).

[2] Bloomberg News. (2021). China's Very Bad Bank: Inside the Huarong Debt Debacle. [online]. Available at: < https://www.bloomberg.com/news/articles/202 1-04-15/china-s-very-bad-bank-inside-thehuarong-debt-debacle>. [Assessed on 20 April 2021].

[3] Bloomberg News. (2021). Huarong Debacle Highlights Problems at Hundreds of Chinese Banks. [online]. Available at: < https://www.bloomberg.com/news/articles/202 1-04-16/huarong-debacle-highlightsproblems-at-hundreds-of-chinese-banks >. [Assessed on 20 April 2021].

[4] Ba, S. (2019). Existing Problems and Development Direction of NPL Securitization. [online]. CBRC. Available at: <https://baijiahao.baidu.com/s?id=162154883 $6223722188 \& w f r=$ spider $\&$ for $=p c \quad>$. [Assessed on 20 April 2021].

[5] CGTN. (2021). 2020: Chinese Banks Dispose $\$ 467 \mathrm{~b}$ in Non-performing Assets. [online]. Available at:< https://news.cgtn.com/news/2021-01-22/2020Chinese-banks-dispose-467-bln-in-nonperforming-assets--

XggBVOE492/index.html >. [Assessed on 20 April 2021].

[6] Deloitte. (2019). Research Report on the Corporate Governance Practices of China's Big Six Commercial Banks. [pdf]. Available at:

https://www2.deloitte.com/cn/en/pages/financi al-services/articles/corporate-governancepractices-of-china-six-largest-commercialbanks-2019.html >. [Assessed on 20 April 2021].

[7] Harris, R. D. (2012). Lehman Brothers: Crisis in Corporate Governance. The Case Research Journal (32), pp. 123-144.

[8] Jiang, F., \& Kim, K,A.. (2020). Corporate Governance in China: A Survey. Oxford. Review of Finance, pp. 733-772.

[9] Jiang, X. (2020). Top Billing for Corporate Governance of Financial Institutions. [online]. China Daily. Available at: <http://www.chinadaily.com.cn/a/202007/04/ WS5effd9eea3108348172572c5.html >. [Assessed on 20 April 2021].

[10] Klepczarek, E. (2017). The Importance of the Board of Directors. Lessons from Lehman's Failure. Ekonomia i Prawo. Economics and Law, 16(1): 59-73. 
[11] Kirkpatrick, G. (2009). The Corporate Governance Lessons from the Financial Crisis. OECD Journal: Financial Market Trends, vol. 2009/1.

[12] Li, J., \&Ng, C, K. (2013). The Normalization of Deviant Organizational Practices: The Nonperforming Loans Problem in China. Journal of Business Ethics, June 2013, Vol. 114, No. 4, Special Issue on The 3rd World Business Ethics Forum: Accountability, Credibility, and Ethicality, pp. 643-653.

[13] Liu, W. (2020). Explainer: Ant's Rise from Payment to Lending Empire. [online]. CGTN. Available at:< https://news.cgtn.com/news/2020-1112/Explainer-Ant-s-rise-from-payment-tolending-empire-VmqT6X2rSw/index.html >. [Assessed on 20 April 2021].

[14] Merle, R. (2018). A Guide to the Financial Crisis - 10 Years Later. [online]. The Washington Post. Available at:< https://www.washingtonpost.com/business/ec onomy/a-guide-to-the-financial-crisis--10years-later/2018/09/10/114b76ba-af10-11e8a20b-5f4f84429666_story.html >. [Assessed on 17 April 2021].

[15] PwC. (2015). China's Non-Performing Loans Are Rising Fast. [pdf]. Spectrum-December 2015 Business Recovery Services. Available at: <https://www.pwchk.com/en/china/chinanpls-opportunities-for-investorsdec2015.pdf >. [Assessed on 22 April 2021].

[16] PwC. (2020). The Chinese NPL Market in 2020: Regulatory Catalyst May Lead to Higher Volumes. [pdf]. Available at: < https://www.pwccn.com/en/deals/publications/ the-chinese-npl-market-in-2020.pdf >. [Assessed on 22 April 2021].

[17] Statista. (2020). Non-performing loan (NPL) ratio of China's listed banks between 2008 and 2018. [online]. Available at: < https://www.statista.com/statistics/235732/non -performing-loan-ration-of-listed-chinesebanks/>. [Assessed on 22 April 2021].

[18] Statista. (2020). Volume of commercial mortgage-backed securities (CMBS) originations in the United States from 2000 to 2020. [online]. Available at: <https://www.statista.com/statistics/942195/v olume-cmbs-originations-usa/ $>$. [Assessed on 22 April 2021].

[19] Statista. (2020). Value of Non-performing Loans (NPL) of Listed Chinese Banks between 2008 and 2018. [online]. Available at: <https://www.statista.com/statistics/235343/v olume-of-non-performing-loans-of-listedchinese-banks/ >. [Assessed on 22 April 2021].

[20] Wiggins, Rosalind Z.; Piontek, Thomas; and Metrick, Andrew. (2019). The Lehman Brothers Bankruptcy A: Overview. Journal of Financial Crises: Vol. 1 : Iss. 1, 39-62.

[21] XinHua News Agency. (2021). NPL ratio of Banks Decreased to 1.92 by the End of 2020. [online]. Available at: <https://baijiahao.baidu.com/s?id=168958636 $1488904426 \& w f r=$ spider $\&$ for $=p c \quad>$. [Assessed on 22 April 2021]. 